Untutored Lines 
Edinburgh Critical Studies in Renaissance Culture

Series Editor: Lorna Hutson

Titles available in the series:

Open Subjects: English Renaissance Republicans, Modern Selfhoods and the Virtue of Vulnerability

James Kuzner

$9780748642533 \mathrm{Hbk}$

The Phantom of Chance: From Fortune to Randomness in SeventeenthCentury French Literature

John D. Lyons

$9780748645152 \mathrm{Hbk}$

Don Quixote in the Archives: Madness and Literature in Early Modern Spain

Dale Shuger

$9780748644636 \mathrm{Hbk}$

Untutored Lines: The Making of the English Epyllion

William P. Weaver

$9780748644650 \mathrm{Hbk}$

Visit the Edinburgh Critical Studies in Renaissance Culture website at www.euppublishing.com/series/ecsrc 


\title{
Untutored Lines
}

The Making of the English Epyllion

\author{
William P. Weaver
}

EDINBURGH

University Press 


\section{To Katherine}

(C) William P. Weaver, 2012

Edinburgh University Press Ltd

22 George Square, Edinburgh

www.euppublishing.com

Typeset in 10.5/13 Adobe Sabon

by Servis Filmsetting Ltd, Stockport, Cheshire, and printed and bound in Great Britain by

CPI Group (UK) Ltd, Croydon, CR0 4YY

A CIP record for this book is available from the British Library

ISBN 9780748644650 (hardback)

ISBN 9780748644667 (webready PDF)

ISBN 9780748649204 (epub)

ISBN 9780748649198 (Amazon ebook)

The right of William P. Weaver

to be identified as author of this work

has been asserted in accordance with

the Copyright, Designs and Patents Act 1988. 